\title{
3D Qrafik Redaktorların Müqayisəli Təhlili
}

\author{
Anar Səmidov \\ AMEA İnformasiya Texnologiyaları İnstitutu, Bakı, Azərbaycan \\ anar@iit.science.az
}

\begin{abstract}
Xülasə - Özünəməxsus təbii məhdudiyyətləri ilə zəngin olan real əşyalar aləmindən fərqli olaraq, alətlərin və materialların kompüter modelləri aləmi yaradıcı insanların özünü büruzə verməsi üçün praktiki cəhətdən qeyri-məhdud imkanlar açır. Bunun üçün ən əlverişli alət fərdi kompüter (FK) və ona uyğun proqram təminatıdır. 3D qrafik redaktorlar süni əşyaların, personajların yaradılması, onların animasiyası və real əşyalarla, interyerlə ahəng təşkil etməsidir. Müasir dövrümüzdə qrafik redaktorları istifadəsi üçün daha perspektivli istiqamətlər mövcuddur. Təqdim edilən ișdə üçölçülü qrafik redaktorlarının müsbət və mənfi keyfiyyətləri araşdırılmış, qarşılıqlı və müqayisəli təhlili aparılmışdır.
\end{abstract}

Açar sözlor-3D qrafika, kompüter qrafikası, 3D texnologiya, 3D model, vizuallașma

\section{GİRIŞ}

Üçölçülü (3 Dimensions-3D) ingilis dilindən tərcümədə virtual yaradıcılıq deməkdir, dizayner tərəfindən yaradılan həcmli hiss olunan kompüter aləmidir.

Bildiyimiz kimi kompüter qrafikasının tətbiq sahəsi həddən artıq çoxdur. Onun hər bir hissəsinin texnoloji prosesdə özünəməxsus fərqliliyi var. Onların hər birisi üçün özünəməxsus poqram təminatı yaradılıb. Qrafik redaktorlar tətbiq sahəsindən asılı olmayaraq bir qayda olaraq hər biri aşağıdakı funksiyalara malik olmalıdır.

- $\quad$ alətlər paneli;

- hazır şəkillər toplusu;

- şriftlər;

- $\quad$ xüsusi effektlər.

3D modelləşdirmə və animasiya yüksək ödəniş tələb edən xidmətdir. Bu sahə özündə çoxlu sayda üçölçülü qrafika üzrə mütəxəssisləribir araya gətirir. Hal-hazırda müasir kompüter qrafikası bazarında gənc mütəxəssislərə təlabat həddən artıq böyükdür [1].

Lakin 3D dizaynerləri hədəflərinə çatmaq üçün uyğun proqram təminatı seçimində müəyyən çətinliklərlə üzləşirlər. Bu çətinliklərin aradan qaldırılması və üçölçülü qrafik redaktorun öyrənilməsinə sərf olunan vaxtın boşa getməməsi üçün hər bir proqramın zəif və güclü tərəflərini analiz etmək lazımdır. Aşağıda üç ölçülü qrafik redaktorlardan ən geniş istifadə olunanlarının müqayisəsiverilmişdir (cədvəl 1, cədvəl 2).

\section{BLENDER 3D QRAFİK REDAKTORU}

Blender 2.59 3D qrafik redaktorunun öyrənilməsi çox asan və eyni zamanda ödənişsizdir. Ödənişsiz olmasına baxmayaraqredaktor yaxşı işləyir. Araşdırmalardan belə qənaətə gəlmək olar ki, redaktor mütəmadi olaraq inkişaf edir və özünün ödənişli rəqibləri ilə rəqabətə girə bilir. Proqramın öyrənilməsinin asanlığını nəzərə aldıqda qənaətə gəlmək olar ki, istənilən şəxs sərbəst olaraq özü bu proqramla işləyə bilər. İlk yarandıqda Blender proqramı kommersiya layihəsi kimi işə başladı, lakin müəyyən müddətdən sonra bağland1, çox çəkmədi ki, əsas açıq kodlarla yenidən fəaliyyətə başladı.

$\mathrm{Bu}$ redaktorun əsas müsbət tərəfi həcminin çox kiçik olmasıdır. $\mathrm{Bu}$ imkanların müqabilində redaktor kifayət qədər işlər görə biləcək həcmdədir. Proqramda üçölçülü qrafikanın yaradılması üçün kifayət qədər alətlər toplusu var. Burada maye və tüstü kimi axar (hərəkətli) effektləri yaratmağa imkan verən modullar var. Blender NURBS səthini redaktə etməyə, personajların avadanlıqlarının sazlanması üçün nəzərdə tutulmuş primitiv imkanlara malikdir.

Proqram Linux və Windows kimi əməliyyat sistemlərində işləyə bilir. $\mathrm{Bu}$ da proqramın daha bir üstünlüyüdür. Aşağı parametrli kompüterlərdə də proqramla işləmək mümkündür [2].

Bütün bu sadalananları nəzərə alaraq Blender redaktorunun müsbət cəhətləri haqqında bunu söyləmək mümkündür:

- $\quad$ olverişlilik və ödənişsiz olması;

- $\quad$ bir çox əməliyyat sistemlərində işləmə qabiliyyəti:

- həcminin kiçik olması;

- zəif konfiqurasiyalı sistemlərə malik kompüterlərdə işləmə bacarı̆̆ı

Çatışmayan, yəni mənfi cəhətləri isə baza versiyasına açılmış sənədlərin daxil olmamasıdır.

\section{3D STUDIO MAX QRAFK REDAKTORU}

Autodesk redaktoru olan 3D StudioMaxmemarlığın vizuallaşmasında böyük rol oynadığı üçün çox məşhurdur. $\mathrm{Bu}$ isə onu deməyə imkan verir ki, tikintiyə başlamazdan öncə tikilməsi nəzərdə tutulan binanın üçölçülü modelini hazırlayaraq sifarişçiyə yekun nəticə kimi təqdim etmək olur. 3D StudioMax proqramı memarlıq layihələri yaratmaq üçün standart qap1 və pəncərədən başlayaraq müxtəlif pilləkənlərədək lazım olan modellərin bir çoxunu özündə cəmləşdirir.Buredaktorda üçölçülü layihənin işıqlandırılması üsulları da mümkündür,həmçinin proqrama kifayət qədər yüksək reallığa nail olmaq üçün fotoreallıq vizuallaşdırıcısı inteqrasiya edilmişdir [3]

Amma 3D StudioMax proqramını öyrənmək o qədər də asan deyil, çünki proqramın çox sayda əlavələri, plaginləri var. Məsələn, Afterburn modulunun istifadəsi real partlayış 
imkanını yaradır, Dreamscape modulu isə təbii landşaftları və suyu modelləşdirmək üçün əlavə alətlərin yaranmasına səbəb olur. 3D StudioMax üçün V-ray, Maxwellrender kimi vizuallaşma sistemləri daha da dəqiq iş görə bilir. Nəticəni reallıqda əks etdirmək üçün 3D qrafikanı mənimsəmək kifayət etmir. Səhnəni düzgün işıqlandırmaq, kamera üçün düzgün bucaq seçmək, materialları və teksturları düzgün seçmək tələb olunur. Bütün bunlar qrafikanın keyfiyyətinə birbaşa təsir göstərir.

3D qrafikalardan geniş istifadəyə kompüter oyunlarında rast gəlinir. Animasiyalı ekran qoruyucularında interfeys və kompüter oyunlarının personajları 3D qrafikasının köməyi ilə yaradılır. Televiziya reklamları və verilişlərinin tərtibatı üçün bir çox arxitektorlar və dizaynerlər 3D qrafikasından istifadə edərək hələ həyatda mövcud olmayan binaların maketini və üçölçülü heykəllərin modellərini hazırlayırlar [4].

3D StudioMax redaktorunun müsbət tərəfləri:

- çoxlu sayda əlavələrin olması;

- ekranın işıqlandırılması üçün daxil olunmuş üsulların varlığı;

- yüksək əməliyyat sisteminə tələbin olmamas1;

- orta imkanlı kompüterlərdə quraşdırılma imkanı.

Proqramın mənfi cəhəti isə mənimsəmədə çətinliyin olması, animasiya və modelləşdirmə üçün proqramın özünün əsas üsullarının azlıq təşkil etməsidir.

\section{AUTOCAD QRAFIKK REDAKTORU}

AutoCAD cəmiyyətin inkişafında həlledici rol oynayan redaktordur.Elmi-texniki tərəqqini təmin etmək avtomatlaşdırılmış sistemlərin, o cümlədən layihələndirmə sistemlərinin yaradılması və tətbiqi üçün bu proqram böyük əhəmiyyət kəsb edir.

Məlum olduğu kimi AutoCAD WINDOWS əməliyyat sistemi platforması əsasında işləyir. Bu paket Autodesk firması tərəfindən tutulmuşdur və avtomatik layihələndirmə sisteminin ən inkişaf etmiş proqram təchizatıdır. Paketdən istifadə etməklə maşınqayırma, elektrotexnika və digər ALS sahələrində çertyojlar layihələndirilir.

Autodesk firmasının yaratdı $\breve{g}_{1}$ AutoCAD qrafik paketi son illərdə bütün dünyada, o cümlədən bizim ölkəmizdə də böyük nüfuz qazanmış və öz geniş imkanlarına görə həyatımızın bütün sahələrində tətbiqini tapmışdır. Bununla bərabər bu proqram paketi ildən ilə öz texniki imkanlarını dayanmadan artırır və versiyadan versiyaya müxtəlif əməliyyatları yerinə yetirən əmrlər kompleksi yaranır. Baxmayaraq ki, müxtəlif ölkələrdə tətbiq edilən avtomatik layihələndirmə sistemləri üçün müxtəlif adlar altında proqramlar yaradılır, lakin AutoCad sistemi bütün bu proqramların baza sistemi olaraq qalır.

AutoCAD proqramından istifadə rahatlı̆̆ına görə fərqlənir, bir layihə üzərində bir neçə mütəxəssisin işləyə bilməsinə imkan verir. $\mathrm{Bu}$ isə imkan verir $\mathrm{ki}$, yekun olaraq bir neçə mütəxəssisin işini bir yerə yerləşdirib, müqayisə edək. Proqramın əsas üstünlüyü obyektlərin 3D modelləşdirilməsidir. $\mathrm{Bu}$ isə artıq dizayn aləmində praktik norma halını almışdır.
AutoCAD proqramının tərtibatçılarının xüsusi əməyi nəticəsində yekun işi 3D printerdə də çap etmək mümkündür [5].

Bütün proqramlar kimi AutoCAD proqramının da mənfi və müsbət xüsusiyyətləri var.

Mənfi cəhətinə misal olaraq verilənlər bazasından məlumatın qrafik obyektlərə bağlanma mürəkkəbliyini göstərmək olar.Artıq iyirmi ilə yaxın fəaliyyət göstərən proqramın bəzi elementləri ilk illərdə aktual olsa da artıq həmin aktuallığını müəyyən qədər itirmək üzrədir. Bununla belə onlar proqramin interfeysində eyni yeri tutur. Misal olaraq, mouse istifadəsinin o qədər də populyar olmadığı vaxtlarda rahat işləmək üçün aktual olan proqramın ekran menyusunu göstərmək olar.

\section{VUE9.5 XSTREAM QRAFIK REDAKTORU}

Üçölçülü qrafika ilə işləyən dizaynerlərin qarşısına qoyulan əsas tələb təbii (ətraf) mühitin modelləşdirilməsidir. Üçölçülü dekorasiya (səhnə, səhnə bəzəyi) nəinki filmin çəkiliş prosesini asanlaşdırır, həmçinin ona çəkilən xərcləri də azaldır. VuexStreamproqramında DAZ 3DB redaktoruna nisbətən obyektlərin birbaşa modelləşdirilməsi üçün alətlər çox azdır. İmkan və funksiyaları baxımından VuexStream proqramının rəqibi yoxdur. Bu proqram 3D landşaftın qurulması üçün çox sayda müxtəlif baza elementlərinə malikdir: materialların ilkin hazır formaları (fraktal teksturalı daşların müxtəlif görünüşü), bitki (yaşıllıq) növləri, müxtəlif işıqlandırmalar və $\mathrm{s}$.

Digər 3D redaktorlardan fərqli olaraq burada ekosistemin imitasiyası var. $\mathrm{Bu}$ isə o deməkdir ki, istifadəçinin təyin etdiyi yeri proqram avtomatik olaraq təbii rənglə, məs., yaşılın uyğun rəngi ilə boyayacaq və hətta ora gül və ağacları elə yerləşdirəcək ki, təsvir daha da təbii alınsın. VuexStream proqramı vizuallaşmanı maksimum dərəcədə mükəmməl formada aparır [6].

Bütün bunlar isə daha da güclü konfiqurasiyalı sistemə malik kompüter tələb edir və modelləşdirmə və vizuallaşdırma prosesi də xeyli vaxt aparır. Ancaq bu proses nəticəsində alınmış real təsvirlə tanış olduqda zəhmət və vaxtın hədər getmədiyini anlamaq olur. Bütün bunları İndiana Cons haqqında çəkilmiş filmə baxanda qiymətləndirmək olar. $\mathrm{Bu}$ filmdəki peyzajlar VuexStream 3D redaktoru vasitəsilə aparılmışdır.

VuexStream üstünlükləri:

- Real təsvirin alınması;

- Ekosistemin imitasiya funksiyasının varlığı.

Çatışmayan cəhətləri:

- Yüksək konfiqurasiyalı sistem tələbi;

- Modelin yaranmasında olan vaxt itkisinin böyük olması.

\section{MAYA QRAFIK REDAKTORU}

Uzun müddət Maya proqramı 3D StudioMax qrafik redaktoru ilə rəqabət aparırdı. Bu rəqabət Autodesk şirkətinə rəqib olan AliasWavefront firmasının Maya proqramının meydana çıxması ilə bitdi. Professional 3D dizaynerlər adətən bu proqramı digərlərinə nisbətən daha çox istifadə edirlər. 
Məs., WaltDisney, Dreamworks kimi iri miqyaslı kompaniyalar bu proqramla işləyirlər. Görülən işlərin nəticəsi artıq göz qabağındadır.

Proqramda üçölçülü qrafikanın yaradılması üçün hər bir lazımi komponent var. Maya proqramı 3D təsvirin yaradılması üçün bütün imkanlarını verir, animasiyadan və modelləşdirmədən tutmuş mürəkkəb teksturadan qatbaqat renderinqədək. Bu redaktor yumşaq və bərk cismin tərkibini araşdıraraq modelləşdirir, personajların saç və saç düzümünü dəqiqliklə düzəldə bilir və s. Osas üstünlüyü PaintEffects komponentinin olmasıdır. Bu komponent vasitəsilə istifadəçi virtual firça ilə üçölçülü obyektlər, iri həcmli bəzəklər, gül, çiçək, ot və s. çəkə bilir. Onu da qeyd edək ki, bu proqramla professional işləməyi öyrənmək kifayət qədər çətindir. Lakin internetdə gərəkli öyrədici vəsaitlərin çox olması bu çətinliyi aradan qaldirır [7].

Proqramın üstünlüklərinə misal olaraq film sənayesində böyük imkanlara malik olmasınıdemək olar.

Çatışmayan cəhətlərindən isə proqramın mənimsənilməsininçətinliyini və baha başa gəlməsini göstərmək olar.

\section{CINEMA 4D QRAFİK REDAKTORU}

Bir neçə il əvvəl Cinema 4D üçölçülü redaktor Maya və 3D StudioMax proqramlarından da zəif idi. Zaman keçdikcə bu proqram bu sahədə liderlik edən Softimage və Lightwave proqramları ilə rəqabətə girə biləcək səviyyədə inkişaf etdirildi. $\mathrm{Bu}$ proqramın inkişafının uzun tarixçəsi var. Onun ilk versiyasi Amiga platforması üçün 1991-ci ildə yaradılıb. MAXON Computer adlı alman kompaniyasının proqramistləri proqramda uzun müddət olan boşluğu aradan qaldırmağa nail olmuşdular. Oyun və filmlərin istehsalı üçün nəzərdə tutulmuş professional proqramların əksəriyyəti çox baha olmuşdur (1000, 10 minlərlə dollar). Ancaq Cinema 4D proqramı qiymət cəhətdən çox uyğun idi. Proqram 3D sahəsinin professionalları üçün maraqlı olmaqda davam edirdi və getdikcə də inkişaf etdirilirdi. Onun arxitekturası çox məntiqi olduğundan yeni öyrənənlər üçün istifadəsi rahatdır.

CəDVӘL 1. QRAFIK REDAKTORLARIN MÜQAYISOLI TЭHLILİ

\begin{tabular}{|c|c|c|c|}
\hline Göstəricilər & Blender 3D & $\begin{array}{c}\text { 3D Studio } \\
\text { Max }\end{array}$ & AutoCAD \\
\hline Oməliyyat sistemi & $\begin{array}{c}\text { Linux, Microsoft } \\
\text { Windows, } \\
\text { Mac OS X }\end{array}$ & $\begin{array}{c}\text { Microsoft } \\
\text { Windows, } \\
\text { Windows NT }\end{array}$ & $\begin{array}{c}\text { Microsoft } \\
\text { Windows, } \\
\text { Mac OS }\end{array}$ \\
\hline Minimum yaddaş & $\sim 2 \mathrm{~GB}$ & $\sim 4 \mathrm{~GB}$ & $\sim 4 \mathrm{~GB}$ \\
\hline $\begin{array}{c}\text { Proqramlaşdirma } \\
\text { dili (Skript) }\end{array}$ & Python & MAXScript & $\begin{array}{c}\text { AutoLISP, } \\
\text { Visual LISP }\end{array}$ \\
\hline Animasiya & + & + & + \\
\hline Render & + & + & + \\
\hline Tətbiq sahəsi & $\begin{array}{c}\text { Vizuallaşma- } \\
\text { real vaxt }\end{array}$ & $\begin{array}{c}\text { Vizuallaşma- } \\
\text { real vaxt } \\
\text { rejimində, } \\
\text { oyun }\end{array}$ & $\begin{array}{c}\text { Vizuallaşma- } \\
\text { real vaxt } \\
\text { rejimində }\end{array}$ \\
\hline Qiymət & Pulsuz & $\begin{array}{l}\$ 910.00 \\
\$ 915.00\end{array}$ \\
\hline
\end{tabular}

DOI: 10.25045/NCSoftEng.2017.79
Proqramin alətləri getdikcə təkmilləşdirilir və əlavələrlə zənginləşdirilir. Hal-hazırda bu proqramda animasiya personajlarının yaradılması, xırdalıqlarla işləmək üsulları, vizuallaşmanın güclü fotorealistik sistemini, həmçinin modelləşdirmənin uyğun alətlərini görmək mümkündür. Proqramın son versiyalarında vizuallaşdırmanın alqoritmi yenilənib və üçölçülü səhnələrin işlənməsi imkanları genişləndirilib. Proqram şamın mumunun işıqlanması zamanı işığın səthdə yayılması, qlobal işıqlandırma və yandırıcı effektlərini hesablamağa imkan verir [8]. Bu proqramın imkanlarından "Ov mövsümü" (Сезон Охоты) tammetrajlı animasiya filminin çəkilişində istifadə edilib.

CəDVӘL 2. QRAFIK REDAKTORLARIN MÜQAYİSӘLI TӘHLILİ

\begin{tabular}{|c|c|c|c|}
\hline Göstəricilər & $\begin{array}{r}\text { Vue9.5 } \\
\text { xStream } \\
\end{array}$ & Maya & Cinema 4D \\
\hline Әməliyyat sistemi & $\begin{array}{c}\text { Microsoft } \\
\text { Windows, Mac } \\
\text { OS }\end{array}$ & $\begin{array}{c}\text { Microsoft } \\
\text { Windows, } \\
\text { Mac OS X, } \\
\text { Linux } \\
\end{array}$ & $\begin{array}{l}\text { Microsoft } \\
\text { Windows, } \\
\text { Mac OS X }\end{array}$ \\
\hline Minimum yaddaş & $\sim 1 \mathrm{~GB}$ & $\sim 4 \mathrm{~GB}$ & $\sim 4 \mathrm{~GB}$ \\
\hline $\begin{array}{l}\text { Proqramlaşdırma } \\
\text { dili (Skript) }\end{array}$ & MEL & $\begin{array}{l}\text { Tcl, MEL } \\
\text { Python }\end{array}$ & $\begin{array}{c}\text { Python, } \\
\text { C.O.F.F.E.E }\end{array}$ \\
\hline Animasiya & + & + & + \\
\hline Render & + & + & + \\
\hline Tətbiq sahəsi & $\begin{array}{l}\text { Vizuallaşma, } \\
\text { film }\end{array}$ & $\begin{array}{l}\text { Vizuallaşma, } \\
\text { Oyun, film }\end{array}$ & $\begin{array}{c}\text { Vizuallaşma- } \\
\text { real vaxt } \\
\text { rejimində, } \\
\text { oyun }\end{array}$ \\
\hline Qiymat & $\$ 1695.00$ & $\$ 765.00$ & $\$ 3,260.00$ \\
\hline
\end{tabular}

\section{NəTİCə}

Vizuallaşdırma - üçölçülü qrafikadan istifadə edən modelləşdirmənin köməyi ilə layihənin son nəticəsinin obyektiv qiymətləndirilməsi və ilkin baxışın ən etibarlı üsuludur. Vizualizasiya daha məzmunludur və sifarişçinin obyekt haqqında təsəvvürünü maksimal dərəcədə genişləndirir. Çertyoj və yaxud maket nə qədər ətraflı işlənsə də gələcəkdəki obyektin təsvirini tam əhatə etmir. Müasir proqram təminatının tətbiqi və professional bədii tərtibat təkcə obyektin özünü deyil, eyni zamanda onu əhatə edən elementləri də reallığa maksimal dərəcədə yaxınlaşdırır. Üçölçülü modelləşdirmə effektivdir və bir sıra üstünlükləri var:layihə haqqında təsəvvürü gücləndirir və sifarişçəyə imkan verir ki, layihələşdirilən obyektin daxili və xarici görünüşünü istənilən hündürlükdən, bucaqdan və yerdən görsün.

Vizuallaşdırmanın məqsədi yalnız memarlıq, mühəndis və dizayner işləri ilə məhdudlaşmır. O, həmçinin kommersiya məqsədi də daşıyır. Yeni layihələrə investisiyaların cəlb olunması da mühüm əhəmiyyət kəsb edir. Reklam və təqdimatlar üçün yalnız texnika, təsvirlər azlıq təşkil etdiyindən, məhz vizuallaşdırmaya yaradıcılıqla yanaşdıqda arzu olunan nəticəni əldə etmək olar. Layihənin sərgilərdə, müsabiqələrdə, nəşrlərdə təqdimatı mərhələsində vizuallaşdırmanın əvəz olunmazlığı özünü daha qabarıq şəkildə göstərir. Araşdırmalar nəticəsində müəyyən olunmuşdur ki, aparılan təhlil dizaynerlərin gördükləri işə uyğun proqram 
təminatı seçimində üzləşdikləri çətinlikləri aradan qaldırmağa kömək edəcək.

\section{ӘDӘВIYYАТ}

[1] А. Л. Хейфец, А. Н. Логиновский, И. В. Буторина, В. Н. Васильева «Инженерная 3D-компьютерная графика», 2015, 464 с.

[2] J. Chronister, "Blender Basics", A Classroom Tutorial Book, 4th Edition, 2011, $178 \mathrm{p}$.

[3] K. Murdock, "3ds Max 2012 Bible", 2011, 1280 p.
[4] А. Шишанов, «Дизайн интерьеров в 3Ds MAX 2012», 2012, 208 с.

[5] A.Ş.Mehdiyev, K.Ş.Ramazanov, "Avtomatik layihələndirmə sistemlərinin əsasları", 2008, $240 \mathrm{~s}$.

[6] “3d-редакторы Vue9.5xstream”, http://cpu3d.com/3d-redaktory-vue95-xstream/

[7] А.Уоткин, К. Ньюэ, «Мауа 7», 2006, 384 с.

[8] В. Зеньковский, «Сinema 4D. Практическое руководство», 2008, $376 \mathrm{c}$. 